\title{
KAJIAN YURIDIS PERLINDUNGAN PEKERJA OUTSOURCING PADA PT. ENERGI PEMBANGKITAN
}

\author{
Oleh: \\ Freddy Sinaga ${ }^{1)}$ \\ Muhammad Yasid ${ }^{2)}$ \\ Universitas Darma Agung, Medan ${ }^{1,2}$ \\ E-mail: \\ freddysinaga08@gmail.com ${ }^{2)}$ \\ yasidfakultashukum@gmail.com ${ }^{1)}$
}

\begin{abstract}
Protection of workers is intended to guarantee the basic rights of workers and guarantee equal opportunities and treatment without discrimination of any kind to realize the welfare of workers and their families while still taking into account developments in the progress of the business world and the interests of employers. That the existence of global economic development and technological advances that are so fast have an impact on the emergence of competition between companies that are so tight that causes companies to appoint outsourcing.
\end{abstract}

Keywords: Workers / Labor Outsourcing

\begin{abstract}
ABSTRAK
Perlindungan terhadap pekerja dimaksudkan untuk menjamin hak-hak dasar pekerja dan menjamin kesamaan kesempatan serta perlakuan tanpa diskriminasi atas apapun untuk mewujudkan kesejahteraan pekerja dan keluarganya dengan tetap memperhatikan perkembangan kemajuan dunia usaha dan kepentingan pengusaha. Bahwa adanya perkembangan ekonomi global dan kemajuan teknologi yang demikian cepat membawa dampak timbulnya persaingan diantara perusahaan yang begitu ketat yang menyebabkan perusahaan melakukan pengangkatan tenaga alih daya (outsourcing).
\end{abstract}

Kata Kunci : Pekerja/Buruh Outsourcing

\section{PENDAHULUAN}

Pada prakteknya perusahaan yang menggunakan outsourcing dalam proses produksi terdapat potensi yang tidak seimbang di dalam kedudukan hubungan kerja antara pekerja dan pengusaha. Keadaan ini menjadikan posisi pekerja menjadi semakin lemah karena kepastian kerja, kepastian upah, jaminan sosial, jaminan kesehatan, pesangon jika terjadi pemutusan hubungan kerja, tunjangan tunjangan dan kepastian lainnya.

Praktek outsourcing pada umumnya lebih menguntungkan perusahaan tetapi tidak demikian dengan pekerja yang selama ini cenderung lebih banyak dirugikan, karena hubungan kerja selalu dalam bentuk tidak tetap/kontrak, upah lebih rendah, jaminan sosial kalaupun ada hanya sebatas minimal, tidak adanya job security serta tidak adanya jaminan pengembangan karir, sehingga dalam keadaan seperti itu pelaksanaan outsourcing akan menyengsarakan pekerja. Perlindungan hukum bagi pekerja/buruh diberikan mengingat adanya hubungan antara pekerja/buruh dengan pengusaha yang menjadikan pekerja/buruh sebagai pihak yang lemah dan termarjinalkan dalam hubungan kerja. Kelompok yang termarjinalkan tersebut sebagian besar dapat dikenali dari parameter kehidupan ekonomi mereka yang sangat rendah, meskipun tidak secara keseluruhan marjinalisasi tersebut 
berimplikasi ekonomi, sehingga perlu dikaji bagaimana pelaksanaan perjanjian kerja antara pekerja outsourcing dengan perusahaan pada PT. Energi Pembangkitan.

\section{TINJAUAN PUSTAKA}

Istilah outsourcing atau contract (work out). Outsourcing memiliki berbagai definisi. Menurut Maurice Greaver yang dikutip oleh IftidaYasar menyatakan definisi outsourcing, yakni: Outsourcing dipandang sebagai tindakan mengalihkan beberapa aktivitasi perusahaan dan hak pengambilan keputusannya kepada pihak lain, dimana tindakan ini terikat dalam suatu kontrak kerja sama.

Menurut Chandra Suwondo, outsourcing dalam bahasa Indonesia disebut sebagai alih daya, sedangkan pengertiannya merupakan pendelegasian operasional dan manajemen harian dari suatu proses bisnis kepada pihak luar (perusahaan penyedia jasa pekerja/buruh). Pendapat serupa juga dikemukakan oleh Amin Widjaja Tunggal yang mendefinisikan outsourcing, adalah proses pemindahan pekerjaan dan layanan yang sebelumnya dilakukan di dalam perusahaan ke pihak ketiga.

$\begin{array}{rcr}\text { Ida } & \text { Hanifah Lubis menulis } \\ \text { pengertian } & \text { outsourcing } & \text { adalah }\end{array}$
pendelegasian operasi dan manajemen harian dari proses bisnis kepada pihak luar (perusahaan penyedia jasa outsourcing. Dengan adanya pendelegasian maka pengelolaan tidak lagi dilakukan oleh perusahaan, melainkan dilimpahkan kepada perusahaan jasa outsourcing.

Selajanjutnya mengacu pada Peraturan perundang-undangan belum ada yang secara tegas dan rinci memberikan definisi outsourcing. Namun pengertian outsourcing dapat terlihat dalam ketentuan Pasal 64 Undang Undang Nomor 13 Tahun 2003 tentang ketenagakerjaan, yakni sebagai berikut: "Perusahaan dapat menyerahkan sebagian pelaksanaan pekerjaan kepadaperusahaan lainnya melalui perjanjian pemborongan pekerjaan ataupenyediaan jasa pekerja/buruh yang dibuat secara tertulis."

Berdasarkan pengertian di atas memunculkan adanya komponen komponen dalam sistem tenaga kerja outsourcing, yaitu pekerja/buruh, perusahaan, pemborong pekerjaan dan penyedia jasa pekerja/buruh. Pekerja/buruh adalah setiap orang yang bekerja dengan menerima upah atau imbalan dalam bentuk lain. Pengusaha adalah:

1. Orang perseorangan, persekutuan, atau badan hukum yang menjalankan suatu perusahaan milik sendiri.

2. Orang perseorangan, persekutuan, atau badan hukum yang menjalankan suatu perusaaan yang bukan miliknya.

3. Orang perseorangan, persekutuan, atau badan hukum yang berada di Indonesia yang mewakili perusahaan sebagaimana yang dimaksud dalam huruf 1 dan 2yang berkedudukan di luar wilayah Indonesia.

Sedangkan yang dimaksud dengan perusahaan yang selanjutnya disebut perusahaan pemberi pekerjaan adalah:

1. Setiap bentuk usaha yang berbadan hukum atau yang bukan berbadan hukum, milik perseorangan, milik persekutuan, atau milik badan hukum, baik milikswasta ataupun milik negara yang mempekerjakan pekerja/buruh denganmembayar upah atau imbalan dalam bentuk lain.

2. Usaha-usaha sosial atau usaha-usaha lain yang mempunyai pengurus dan mempekerjakan orang lain dengan membayar upah atau imbalan dalam bentuk lain.

Kemudian yang dimaksud dengan pemborong pekerjaan yaitu penyerahan sebagian pelaksanaan pekerjaan/pemborongan pekerjaan dari perusahaan pemberi pekerjaan kepada perusahaan penerima pemborongan 
pekerjaan. Sedangkan penyedia jasa pekerja/buruh atau bisa disebut dengan vendo radalah perusahaan berbadan hukum yang dalam kegiatan usahanya menyediakanjasa pekerja/buruh untuk dipekerjakan di perusahaan pemberi pekerjaan.

Pada dasarnya memang hampir sama antara pemborong pekerjaan dengan penyedia jasa pekerja/buruh, hanya saja untuk pemborongan pekerjaan lebih cenderung ke arah sub contracting pekerjaan dibandingkan dengan tenaga kerja, sedangkan penyedia jasa pekerja/buruh (outsourcing) mempunyai tujuan yang strategis dalam jangka panjang dan menyerahkannya pada pihak yang lebih professional dalam hubungan kemitraan bisnis.

\section{METODE PELAKSANAAN}

Metode pelaksanaan menggunakan yuridis normatif dan penelitian empiris. Yuridis normatif dan penelitian empiris, menggunakan data primer dan sekunder. Metode pendekatan penelitian ini bersifat deskriptif analisis, yaitu jenis penelitian yang sifatnya mendiskripsikan atau menjelasakan peraturan-peraturan yang ada dan saat ini berlaku sebagai hukum positif. Dalam pendekatan ini yang dikaji adalah hukum ketenagakerjaan yang berkaitan dengan perlindungan terhadap pekerja/buruh alih daya (outsourcing) yang dirugikan hak haknya, dengan melihat sejauh mana pertanggungjawaban pelaku usaha ketika pelaku usaha melanggar kewajibannya terhadap hak hak pekerja/buruh alih daya (outsourcing). Analisis data dilakukan secara kualitatif yakni pemilihan teori-teori, asas-asas, norma-norma, doktrin, dan pasal-pasal di dalam perundangundaangan terpenting yang relevan permasalahan.

\section{HASIL dan PEMBAHASAN}

\section{PELAKSANAAN TENAGA KERJA OUTSOURCING DI PT. ENERGI}

\section{PEMBANGKITAN}

Pelaksanaan sistem tenaga kerja outsourcing di PT. Energi Pembangkitan merupakan pemberian pekerjaan penyediaan jasa tenaga kerja (PJTK) di sektor pembangkitan Medan, dimana PT. PLN (Persero) Pembangkitan Sumatera Bagian Utara memborongkan pelaksanaan pekerjaan kepada PT. Energi Pembangkitan sebagaimana termuat dalam Surat Perjanjian Nomor 028.Pj/61/KITSBU/2012 dan Nomor 093/PT-EP/II/2012 tertanggal kontrak 29 Februari 2012 tentang Pekerjaan Penyediaan Jasa Tenaga Kerja (PJTK) di Sektor Pembangkitan Medan PT. PLN (Persero) Pembangkitan Sumatera Bagian Utara.

Lingkup pekerjaan untuk melaksanakan sebagian tugas pekerjaan di lingkungan Sektor Pembangkitan Medan PT. PLN (Persero) Pembangkitan Sumatera Bagian Utara kepada PT. Energi Pembangkitan yang terdiri dari:

1. Pekerjaan Layanan Administrasi Perkantoran meliputi: Bagian Sekretariat, dan Bagian Administrasi.

2. Pekerjaan Satuan Pengaman.

3. Pekerjaan Operator.

4. Pekerjaan Tenaga Pemeliharaan.

Tugas Layanan Administrasi Perkantoran terdiri dari :pertama, Bagian Sekretariat, antara lain tugasnya Menerima surat masuk extern dan intern. Mengagendakan surat masuk extern clan intern. Mendistribusikan surat masuk ke bidang terkait. Membuat SPPD dan perinciannya. Mengarsipkan surat masuk. Melaksanakan tugas dari atasan. Mengagendakan surat keluar dan mengirim kepada yang dituju. Mengagendakan facsimile dan mengirim kepada yang dituju. Memantau surat dan facsimile yang dikirim melalui telepon. Mendistribusikan surat dan facsimile yang masuk kepada bidang terkait. Menomori nota dinas dan surat keputusan General Manager. Membuat monitoring pengendalian surat keluar. Membantu 
tugas-tugas di bagian umum. Melakukan pesanan yang menyangkut dengan konsumsi dan kebutuhan kantor Sektor Pembangkitan Medan. Membuat nota dinas tagihan konsumsi rapat dinas pegawai. Melayani Acara Rapat (karyawan Sekretariat dan Umum). Kedua Bagian Administrasi, antara lain : Membantu tugas-tugas administrasi pada ruangan Manajer dan Asisten Manajer. Membantu pelaksanaan tim kontrak. Menyusun dan merapikan arsip/dokumen kontrak.

Pekerjaan Satuan Pengaman selama menjalankan tugasnya, anggota satpam harus selalu memakai pakaian seragam yang bersih dan rapi serta menggunakan tanda-tanda pengenal sesuai ketentuan berlaku dan selalu membawa kartu anggota dan surat yang penting lainnya. Lingkup Tugas Satuan Pengaman, antara lain :Setiap anggota satpam di haruskan mengetahui tempattempat dan sarana-sarana yang penting, termaksud kotak-kotak tanda bahaya didalam instalasi yang menjadi tanggung jawab pengamanannya dan segera membunyikan tanda-tanda bahaya apabila terjadi kebakaran. Setiap anggota satpam harus mematuhi jadwal pelaksanaan tugasnya clan bila berhalangan agar dengan segera memberitahukan kepada atasannya.Setiap anggota satpam diharuskan untuk menguasai Tata Cara menggunakan Pemadam Kebakaran dan selalu siap untuk menggunakannya. Setiap anggota satpam harus mengetahui nomor-nomor telepon yang penting khususnya nomor-nomor telepon satuan-satuan Polri/TNI, Dinas Kebakaran, Rumah Sakit dan Puskesmas yang terdekat untuk keperluan permintaan pertolongan. Setiap anggota satpam harus segera menghubungi satuan Polri bila akan adanya pelanggaran hukum atau adanya bahaya bahaya yang mengancam dilingkungan dikawasan kerjanya. Setiap anggota satpam didalam waktu menjalankan tugasnya tidak melibatkan diri dalam percakapan yang tidak ada manfaatnya. Setiap anggota satpam tidak dibenarkan menjadi perantara (calo) dalam hal pengurusan surat-menyurat, menyambung/penambahan aliran listrik dan jasa-jasa lainnya antara konsumen/pihak ketiga dengan PLN. Menjaga keamanan dan ketertiban lalu lintas orang, karyawan PLN, barang dan instalasi. Keluar masuk barang harus dengan izin dan telah di check kebenarannya oleh anggota satpam. Menjaga keamanan/menertibkan tamu yang masuk. Tidak dibenarkan tamu masuk tanpa izin dan telah di check kebenarannya oleh anggota satpam. Melakukan serah terima regu jaga yang lama dengan regu jaga yang baru dengan teliti.Nyalakan lampu penerangan bila hari telah senja dan matikan dipagi hari.Petugas baru pengganti hadir 30 menit sebelum serah terima dilakukan. Melaporkan segera bila terjadi gangguan keamanan dan ketertiban dan kebakaran kepada piket PT PLN (Persero) Sektor Pembangkitan Medan, kepala Unit setempat, Kepala Bagian Teknik, Kepala Seksi Operasi, POLRI/TNI. Membuat laporan bulanan keamanan Unit yang dijaga kepada PT PLN (Persero) Sektor Pembangkitan Medan.Melakukan pengontrolan kenderaan yang diawasi setiap 1 (satu) jam sekali dan bunyikan lonceng 1 (satu) jam sekali pada malam hari.Setiap paginya pukul 06.00 Wib Anggota jaga harus menaikkan bendera merah putih dan menurunkan tepat pada Pukul 18.00 Wib.

Lingkup Tugas Operator, antara lain Mengoperasikan Unit pembangkit sesuai dengan Standing Operation Procedure (SOP) yang telah ditentukan. Melakukan pencatatan parameter parameter sesuai dengan format logsheet yang telah disediakan, baik kolom parameter maupun skala periodic waktu pencatatannya. Melakukan pengamatan terhadap operasi mesin/unit pembangkit agar unit dapat beroperasi dengan baik dan aman. Melakukan dan memelihara kebersihan lokasi pekerjaan (power house). Menjaga barang inventaris perusahaan yang terdapat di lokasi pekerjaan (power house area), selama 
lainMengoperasikan Unit pembangkit sesuai dengan Standing Operation Procedure (SOP) yang telah ditentukan. Melakukan pencatatan parameter parameter sesuai dengan format logsheet yang telah disediakan, baik kolom parameter maupun skala periodic waktu pencatatannya.Melakukan pengamatan terhadap operasi mesin/unit pembangkit agar unit dapat beroperasi dengan baik dan aman.Melakukan dan memelihara kebersihan lokasi pekerjaan (power house).Menjaga dan bertanggung jawab atas segala barang barang inventaris perusahaan yang terdapat di lokasi pekerjaan (power house area), selama jam/waktu shiftnya.Melakukan pelaporan sesuai keadaan unit dengan waktu pelaporan yang telah ditentukan.Melakukan pelaporan bila terjadi gangguan pada unit pembangkit yang diawasinya.Membuat berita acara serah terima tugas pada setiap akhir tugas shiftnya, log book dan menandatanganinya.Operator pengganti harus berada di tempat pekerjaan 10 (sepuluh) menit sebelum petugas operator yang digantikan pulang.Petugas operator tidak dibenarkan pulang apabila operator pengganti belum hadir. Dilarang meninggalkan unit pada saat jam tugasnya dan menggantikannya kepada orang lain tanpa ijin tertulis dari Manajer unit/Kepala Unit.

Selanjutnya kewajiban pekerja/buruh di PT. Energi Pembangkitan terlihat pada Surat Perjanjian Kerja Waktu Tertentu (outsourcing) Nomor. 005.PJ.OS.SPM/EP/I/2014 antara PT. Energi Pembangkitan yang diwakili oleh Luther Sihombing selaku Direktur PT. Energi Pembangkitan dan Humusor Parnasipan Sihombing selaku pekerja/buruh sebagai jabatan Administrasi Perkantoran di PT. PLN (Persero) Pembangkitan Sumatera Bagian Utara unit kerja Paya Pasir Medan dimana jangka waktu kerja tertentu ini berlaku selama 10 (sepuluh) bulan sejak tanggal 1 Januari 2014 sampai dengan tanggal 31
Oktober 2014 terlihat pekerja/buruh mempunyai kewajiban berikut.

Pekerja/buruhpada

jabatan

Administrasi Perkantoran bagian

Sekretariat, antara lain tugasnya Menerima surat masuk extern dan intern. Mengagendakan surat masuk extern clan intern. Mendistribusikan surat masuk ke bidang terkait. Membuat SPPD dan perinciannya. Mengarsipkan surat masuk. Melaksanakan tugas yang diperintahkan oleh atasan. Mengagendakan surat keluar dan mengirim kepada yang dituju. Mengagendakan facsimile dan mengirim kepada yang dituju. Memantau surat dan facsimile yang dikirim melalui telepon. Mendistribusikan surat dan facsimile yang masuk kepada bidang terkait. Menomori nota dinas dan surat keputusan General Manager. Membuat monitoring pengendalian surat keluar. Membantu tugas-tugas di bagian umum. Melakukan pesanan yang menyangkut dengan konsumsi dan kebutuhan kantor Sektor Pembangkitan Medan. Membuat nota dinas tagihan konsumsi rapat dinas pegawai. Melayani Acara Rapat (karyawan yang bertugas pada bagian Sekretariat dan Umum).

Pekerjaan yang ditetapkan itu pada umumnya harus dilakukan oleh pekerja/buruh itu sendiri, lebih-lebih jika yang menjadi dasar perjanjian kerja adalah kecakapan dan pekerja/buruh yang bersangkutan.Pada umumnya pekerja/buruh tidak berhak dengan begitu saja mengirimkan seorang penggantinya. Misalnya: jika seorang pekerja/buruh memberitahukan tidak masuk kerja, karena bepergian dan mengirimkan penggantinya, PT. PLN (Persero) Pembangkitan Sumatera Bagian Utara tidak wajib dengan begitu saja untuk menerima pengganti itu. Hal ini sesui dengan KUHPerdata, Pasa11603a, "Buruh wajib melakukan sendiri pekerjaannya, hanya dengan izin majikan ia dapat menyuruh orang lain menggantikannya." Begitu juga sebaliknya hak majikan atas pekerjaan buruh itu tidak dapat diserahkan dengan begitu saja 
kepada orang lain.

Selanjutnya jika pekerja/buruh telah bersedia melakukan pekerjaannya sesuai dengan perjanjian kerka waktu tertentu yang dibuat natar pekerja/buruh dengan PT. Energi Pembangkitan sebagaimana yang dituangkan dalam surat perjanjian kerja tertulis, maka pekerja/buruh akan mendapatkan hak-haknya diantaranya terlihat pada Surat Perjanjian Kerja Waktu Tertentu (outsourcing) Nomor. 001.PJ.OS.SPM/EP/I/2014, pekerja/buruh berhak: menerima penghasilan setiap bulannya sebesar Rp. 1.870.000,- (satu juta delapan ratus tujuh puluh ribu rupiah) dan tunjangan transport sebesar Rp. 200.000,(dua ratus ribu rupiah), begitu juga bila lembur mendapatkan upah kerja lembur per jam sebesar Rp. 7.000,- (tujuh ribu rupiah), dan uang makan Rp.10.000,(sepuluh ribu rupiah), seterusnya pekerja/buruh dapat meningggalkan pekerjaannya dengan mendapatkan upah penuh yang antara lain karena:

1. Perkawinan pekerja/buruh sendiri selama 4 hari

2. Istri melahirkan selama 3 hari

3. Kematian istri pekerja/suami/anak/orang tua/mertuapekerja selama 3 hari

4. Perkawinan anak pekerja/buruh sendiri selama 2 hari

5. Baptis/Khitan anak pekerja/buruh selama 1 hari.

Sedangkan pada Surat Perjanjian

Kerja Waktu Tertentu (outsourcing) Nomor. $\quad$ 005.PJ.OS.SPM/EP/I/2014, pekerja/buruh berhak: menerima penghasilan setiap bulannya sebesar Rp. 1.724.000,- (satu juta tujuh ratus dua puluh empat ribu rupiah) dengan rincian gaji pokok sebesar Rp. 1.556.000,- (satu juta lima ratus lima puluh enam ribu rupiah), dan transportasi Rp. 168.000,- (seratus enam puluh delapan ribu rupiah). Selanjutnya pekerja/buruh mendapat imbalan lain berupa program jamsostek, diantaranya jaminan kecelakaan kerja, sebesar $1,74 \%$ dari upah, jaminan kematian sebesar $0.30 \%$ dari upah, jaminan hari tua sebesar $5,7 \%$ dari upah, jaminan pemeliharaan kesehatan sebesar $6 \%$ dari upah bagi pekerja/buruh yang sudah berkeluarga dan 3\% dari upah bagi pekerja/tenaga kerja yang belum berkeluarga. Pekerja/buruh juga mendapatkan pakain dinas minimal 2 (dua) stell per tahun, dan juga mendapatkan cuti setelah bekerja 12 (dua belas) bulan berturut turut atau terpisah selama 12 (dua belas) hari kerja dalam masa satu tahun berjalan. Begitu juga pekerja/buruh dapat meningggalkan pekerjaannya dengan mendapatkan upah penuh yang antara lain karena melangsungkan pernikahan diberikan izin selama 4 hari kerja, Istri melahirkan selama 3 hari Kematian istri pekerja/suami/anak/orang

tua/mertuapekerja selama 3 hari, Perkawinan anak pekerja/buruh sendiri selama 2 hari dan Baptis/Khitan anak pekerja/buruh selama 1 hari.

$\begin{array}{llr}\text { Jadi hematnya dengan } & \text { dasar } \\ \text { ketentuan perjanjian kerja antara } & \text { an } \\ \text { pekerja/buruh dengan PT. } & \text { Enegri } \\ \text { Pembangkitan yang dipekerjakan } & \text { di PT. } \\ \text { PLN (Persero) Pembangkitan } & \text { Sumatera }\end{array}$
Bagian Utara menjadi hukum yang mengikat, pekerja/buruh mulai melakukan pekerjaan sebagai kewajiban tenaga kerja, serta menaati perintahperintah atau petunjuk yang ada di unit tempat pekerja/buruh bekerja.

\section{Kewajiban Penyedia Tenaga Kerja Outsourcing PT. Energi Pembangkitan}

Kewajiban penyedia tenaga kerja outsourcing PT. Energi Pembangkitan merupakan hak-hak pekerja/buruh yang bekerja pada PT. PLN (Persero) Pembangkitan Sumatera Bagian Utara, berdasarkan lampiran surat perjanjian Nomor $028 . P j / 61 / K I T S B U / 2012$ dan juga lampiran surat perjanjian Nomor 093/PTEP/II/2012 tertanggal 29 Februari 2012, dimana daftar tenaga kerja pekerja/buruh sebanyak 75 (tujuh puluh lima) tenaga kerja outsourcing yang bekerja di berbagai bagian/seksi di PT. PLN (Persero) Pembangkitan Sumatera Bagian Utara. 
Berdasarkan Kewajiban-kewajiban pokok, menurut peraturan yang ada, diletakkan pada pemberi kerja/majikan ialah mengatur pekerjaan, mengatur tempat kerja, memberi surat keterangan. Kewajiban tambahan, yaitu mengadakan buku upah, buku pembayaran upah, daftar bahari dan lain-lain.Kewajiban umum terdapat dalam Pasal 1602 KUHPerdata, "majikan pada umumnya wajib melakukan atau tidak melakukan sesuatu yang dalam keadaan yang sama seharusnya dilakukan atau tidak dilakukan oleh seorang majikan yang baik."

$$
\text { Kewajiban PT. Energi }
$$

Pembangkitan untuk mengatur pekerjaan dan mengatur tempat kerja, pada hakekatnya merupakan kewajiban untuk mengusahakan menjaga dan memelihara kesehatan, keselamatan dan kesusilaan pekerja/buruh, karena hal tersebut merupakan masalah kesehatan kerja dan keamanan kerja. Jadi hematnya upah pekerja/buruh yang ada di PT. Energi Pembangkitan merupakan satusatunya bekal hidupnya dan keluarganya. Karena itu diadakan pelbagai ketentuan dalam perundang-undangan sebagai jaminan bahwa upah itu benar-benar akan dibayarkan oleh majikan dan diterima oleh pekerja/buruh sendiri.

Membayar upah, merupakan kewajiban pokok PT. Energi Pembangkitan dan merupakan hak pekerja/buruh atas pekerjaan yang telah dilakukan sesuai dengan perjanjian kerja. Upah biasanya ditetapkan oleh kedua belah pihak baik dalam perjanjian kerja, dalam peraturan PT. Energi Pembangkitan. Bila kedua belah pihak telah sepakat, penetapannya akan dilakukan oleh PT. Energi Pembangkitan secara sepihak. Dengan sendirinya PT. Energi Pembangkitan harus menetapkannya dengan itikad baik.Jika PT. Energi Pembangkitan melanggar itikad baik ini, buruh dapat menuntut upah sesuai dengan upah minimal yang telah ditetapkan oleh pemerintah. Akan tetapi upah pekerja/buruh yang ada di PT. Energi
Pembangkitan masih relatif yang tidak dibawah standar upah minimum berdasarkan wilayah provinsi sebesar $\mathrm{Rp}$. 1.700.000,- sebagai contoh halmana terlihat dalam Surat Perjanjian Kerja Waktu Tertentu (outsourcing) Nomor. 005.PJ.OS.SPM/EP/I/2014 dan juga Surat Perjanjian Kerja Waktu Tertentu Nomor. 005.PJ.OS.SPM/EP/I/2014 sebagaimana telah diuraikan pada paragraf sebelumnya.

Penetapan upah tergantung dari keterangan yang dapat tercatat dalam pembukuan PT. Energi Pembangkitan. Dalam praktek terjadi pada penetapan bagian keuntungan dan provisi.Pekerja/buruh berhak minta diberitahukan surat bukti yang diperlukan untuk mengetahui keterangan tersebut. Jika pekerja/buruh berhak atas sebagaian keuntungan, keuntungan itu adalah yang ternyata dari daftar perhitungan laba rugi yang dibuat dengan itikad baik.

$\begin{array}{lr}\text { PENYELESAIAN } & \text { PERSELISIHAN } \\ \text { HUBUNGAN } & \text { INDUSTRIAL } \\ \text { PEKERJA/BURUH } & \text { OUTSORCING } \\ \text { DENGAN PT. } & \text { ENERGI } \\ \text { PEMBANGKITAN } & \end{array}$

Perselisihan identik dengan membahas masalah konflik. Perselisihan ini merupakan luapan emosi yang mempengaruhihubungan seseorang dengan orang lain. Jadi, masalah perselisihan akan hal yang lumrah karena tetah menjadi kodrat manusia. Jadi langkah strategis yang perlu bagaimana seseorang memannejeman perselisihan itu dengan baik untuk mendapatkan solusi yang tepat dan akurat. Begitu juga mengenai perselisihan hubungan industrialterkadang tidak dapat dihindari.

Berdasrakan ketentuan Pasal 1 angka 22 Undang Undang Nomor 13 Tahun 2003 tentang Ketenagakerjaan dan Pasal 1 angka 1 Undang-Undang Nomor 2 tahun 2004 tentang Penyelesaian Perselisihan Hubungan Industrial menyatakan bahwa:

"Perselisihan hubungan industrial ialah 
perbedaan pendapat yang mengakibatkan pertentangan antara pengusaha atau gabungan pengusaha dengan pekerja/buruh atau serikat pekerja/serikat buruh karena adanya perselisihan mengenai hak, perselisihan kepentingan, dan perselisihan pemutusan hubungan kerja serta perselisihan antara serikat pekerja/serikat buruh hanya dalam satu perusahaan."

Berdasarkan pengertian perselisihan hubungan industrial di atas, terlihat ada 4 (empat) jenis perselisihan hubungan industrial yakni: (1) Perselisihan hak; (2) Perselisihan kepentingan; (3) Perselisihan pemutusan hubungan kerja; dan (4) Perselisihan antar serikat pekerja/serikat buruh.

\section{Penyelesaian Perselisihan Hubungan Industrial di PT. Energi Pembangkitan Dengan Pekerja/Buruh Outsourcing}

Hak atas pekerja/buruh outsourcing

pada PT. Energi Pembangkitan sudah sesuai dengan Permen Tenaga Kerja dan Transmigrasi Nomor 19 Tahun 2012 dalam Pasal 29 Ayat (3) Hak-hak pekerja meliputi :

a. Hak atas cuti apabila telah memenuhi syarat masa kerja;

b. Hak atas jaminan sosial;

c. Hak atas tunjangan hari raya;

d. Hak istirahat paling singkat 1 (satu) hari dalam 1 (satu) minggu;

e. Hak menerima ganti rugi dalam hal hubungan kerja diakhiri oleh perusahaan penyedia jasa pekerja/buruh sebelum perjanjian kerja waktu tertentu berakhir bukan karena kesalahan pekerja;

f. Hak atas penyesuaian upah yang diperhitungkan dari akumulasi masa kerja yang telah dilalui; dan

g. Hak-hak lain yang telah diatur dalam peraturan perundang-undangan dan/atau perjanjian kerja sebelumnya.

Dengan memperhatikan asas-asas yang melandasi norma hukum, seperti asas beritikad baik, kesepakatan, kebebasan berkontrak, serta asas kepentingan hidup bagi pihak yang lemah, tersurat dalam ketentuan Pasal 50, dan Pasal 52 Undang Undang Ketenagakerjaan, memberi deskripsi, bahwa perjanjian kerja yang tidak memenuhi persyaratan hukum dapat dibatalkan atau batal demi hukum. Akan tetapi hak pekerja/buruh pada PT. Energi Pembangkitan berdasarkan Surat Perjanjian Kerja Waktu Tertentu (outsourcing) Nomor. 005.PJ.OS.SPM/EP/I/2014 antara PT. Energi Pembangkitan yang diwakili oleh Luther Sihombing selaku Direktur PT. Energi Pembangkitan dan Humusor Parnasipan Sihombing selaku pekerja/buruh sebagai jabatan Administrasi Perkantoran di PT. PLN (Persero) Pembangkitan Sumatera Bagian Utara unit kerja Paya Pasir Medan dimana jangka waktu kerja tertentu ini berlaku selama 10 (sepuluh) bulan sejak tanggal 1 Januari 2014 sampai dengan tanggal 31 Oktober 2014 terlihat pekerja/buruh tersebut ada haknya yang tidak dipenuhi oleh PT. Energi Pembangkitan, dimana pekerja/buruh (Humusor Parnasipan Sihombing) tidak menerima hak Extra Puding sebesar Rp. 99.000,- x 5 bulan berarti sebesar Rp.495.000,-, Rapel Gaji 2 bulan yaitu Rp. 398.000,- Lembur 5 bulan Rp. 896.000, Gaji 5 bulan x Rp. 2.062.000, berarti Rp. 10.310.000,- dengan Total seluruhnya Rp. 12.099.000,-.

Akibat tidak terpenuhinya hak dan kewajiban dalam suatu perjanjian tenaga kerja akan membawa dampak perselisihan ataupun sengketa bagi para pihak. Adanya sengketa para pihak ini pada akhirnya akan mencari jalan untuk penyelesaiannya. Penyelesaian perselisihan hubungan industrial ini dapat ditempuh berbagai lembaga yakni mulai dari bipartit, konsiliasi, arbitrase, mediasi, dan melalui pengadilan hubungan industrial sebagaimana yang telah diuraikan pada pembahasan sebelumnya. Maka penyelesaian perselisihan hubungan 
industrial di PT. Energi Pembangkitan dilaksanakan melalui lembaga bipartit dimanaupaya penyelesaian melalui bipartit proses perundingan yang dilakukan antara dua pihak, yaituPT. Energi Pembangkitanselaku pengusaha dengan pihak pekerja/buruh (Humusor Parnasipan Sihombing). Perundingan bipartit yang dilaksanakan merupakan upaya musyawarah untuk mufakat namun bipartit yang dilaksanakan gagal.

Berkenaan dengan gagalnya penyelesaian perselisihan hubungan industrial melalui lembaga bipartit, selanjutnya PT. Energi Pembangkitanselaku pengusaha dengan pihak pekerja/buruh (Humusor Parnasipan Sihombing) melanjutkan upaya penyelesaian ke lembaga Mediasi, dalam hal ini pihak mediator hubungan industrialnya dari Dinas Tenaga Kerja dan Tarnsmigrasi Smatera Utara, yang diwakili oleh mediator Maurid Siahaan dan Raijon.

Upaya penyelesaian melalui mediasi yang dilaksanakan PT. Energi Pembangkitanselaku pengusaha dengan pihak pekerja/buruh (Humusor Parnasipan Sihombing) dengan pihak mediator Dinas Tenaga Kerja dan Tarnsmigrasi Sumatera Utaramelalui musyawarah berhasil dilaksanakan hal mana sesuai dengan surat Perjanjian Bersama dimana PT. Energi Pembangkitan akan memenuhi kewajibannya untuk memberikan hak pekerja/buruh sesuai dengan tuntutan pembayaran Extra Puding sebesar Rp. 99.000,- X 5 bulan berarti sebesar Rp.495.000,-, Rapel Gaji 2 bulan yaitu Rp. 398.000,- Lembur 5 bulan Rp. 896.000, Gaji 5 bulan x Rp. 2.062.000, berarti Rp. 10.310.000,- dengan Total seluruhnya $\mathrm{Rp}$. 12.099.000,- dimana hak buruh ini telah dibayarakan oleh PT. Energi Pembangkitan ke rekening pekerja/buruh.

\section{KESIMPULAN DAN SARAN}

\section{A. Kesimpulan}

$\begin{array}{lccr}\text { 1. Pengaturan } & \text { sistem } & \text { tenaga } & \text { kerja } \\ \text { outsorcing } & \text { pada } & \text { PT } & \text { Energi } \\ \text { Pembangkitan } & \text { telah } & \text { sesuai } & \text { dengan }\end{array}$

aturan hukum Pasal 64 undang undang keterankerjaan. Dimana PT. PLN (Persero) Pembangkitan Sumut memborongkan pelaksanaan pekerjaan kepada PT. Energi Pembangkitan sebagaimana diantaranya termuat dalam Surat Perjanjian Nomor 028.Pj/61/KITSBU/2012 dan Nomor 093/PT-EP/II/2012 tertanggal kontrak 29 Februari 2012 tentang Pekerjaan Penyediaan Jasa Tenaga Kerja (PJTK) di Sektor Pembangkitan Medan PT. PLN (Persero) Pembangkitan Sumut.

2. Kewajiban antara pekerja/buruh outsorcing dengan PT. Energi Pembangkitan hal yang mutlak untuk dilaksanakan, kewajiban pekerja/buruh merupakan hak PT. Energi Pembangkitan, sebaliknya kewajiban PT. Energi Pembangkitan merupakan hak bagi pekerja/buruh. Berdasarkan Surat Perjanjian Kerja Waktu Tertentu (outsourcing) Nomor 005.PJ.OS.SPM/EP/I/2014 antara PT. Energi Pembangkitan dan Humusor Parnasipan Sihombing selaku pekerja/buruh. Para pihak mempunyai hak dan kewajiban diantaranya pekerja/buruh berhak mendapatkan upah/gaji, cuti, uang lembur, dan mempunyai kewajiban untuk melaksanakan pekerjaan sebagai administrasi yang dipekerjakan pada PT. PLN (Persero) Pembangkitan Sumatera Bagian Utara.

3. Penyelesaian perselisihan hubungan industrial pekerja/buruh outsorcing dengan PT. Energi Pembangkitan dapat ditempuh mulai dari bipartit, konsiliasi, arbitrase, mediasi, dan melalui pengadilan hubungan industrial. Berdasarkan kasus yang ada di PT. Energi Pembangkitan penyelesaian perselisihan hubungan industrial terkait Perselisihan hak dimana perselisihan timbul karena tidak dipenuhinya hak Extra Puding sebesar Rp. 99.000,- x 5 bulan berarti sebesar Rp.495.000,-, Rapel Gaji 2 bulan yaitu Rp. 398.000,Lembur 5 bulan Rp. 896.000, Gaji 5 
bulan x Rp. 2.062.000, berarti Rp. 10.310.000,- dengan Total seluruhnya Rp. 12.099.000,- yang dialami oleh Humusor Parnasipan Sihombing penyelesaiannya dilaksanakan melalui lembaga bipartit, namun perundingannya gagal selanjutnya melalui lembaga mediasi yang di mediasi oleh Dinas Tenaga Kerja dan Transmigrasi Sumatera Utara melalui musyawarah berhasil dilaksanakan dengan surat Perjanjian Bersama dimana PT. Energi Pembangkitan memenuhi kewajibannya untuk memberikan hak pekerja/buruh sesuai dengan tuntutan pembayaran.

\section{DAFTAR PUSTAKA}

Abdussalam, H.R. dan Adri Desasfuryanto, Hukum Ketenagakerjaan (Hukum Perburuan), PTIK, Jakarta: 2015.

Amiruddin dan Asikin, Zainal.,Pengantar Metode Penelitian Hukum, (Jakarta: Raja Grafindo Persada, 2006).

Khakim, Abdul., Dasar Dasar Hukum Ketenagakerjaan Indonesia, Citra Aditya Bakti, Bandung: 2014.

Koentjoroningrat, Metode-Metode Penelitan Masyarakat, Jakarta: Gramedia Pustaka Utama, 1997.

Lubis, Ida Hanifah., Hukum Ketenagakerjaan Indonesia, Ratu Jaya, Medan: 2012.

Maimun, Hukum Ketenagakerjaan : Suatu Pengantar, Jakarta: Pradnya Paramita, 2007.

Marbun, Jaminuddin., Manfaat Perjanjian Kerja Bersama Dalam Hubungan Industrial Bagi Pengusaha dan Pekerja/Buruh, USU Press, Medan:2013.

Saleh, Mohammad H, dan Mulyadi, Lilik, Seraut Wajah Pengadilan Hubungan Insdustrial Indonesia, Citra Aditya Bakti, Bandung: 2012.

Soemitro,Ronny Hanitijo.,Metodologi
Penelitian Hukum, Ghalia Indonesia,Jakarta:1982.

Sukanto, Soejono., Ringkasan Metodologi Penelitian Hukum Empris, Indonesia Hillco, Jakarta:1990.

Supriyanto, Hari., Perubahan Hukum Privat ke Hukum Publik, Studi Hukum Perburuhan diIndonesia, Universitas Atma Jaya, Yogyakarta: 2004.

Suwondo, Chandra., Outsourcing Implementasi di Indonesia, Elex Media Komputindo, Jakarta:2003.

Trijono, Rachmat., Pengantar Hukum Ketenagakerjaan, Papas Sinar Sinanti, Jakarta: 2014.

Tunggal, Amin Widjaja., Outsourcing Konsep dan Kasus, Harvarindo, Jakarta: 2008.

Widodo, Hartono., dan Judiantoro, Segi Hukum Penyelesaian Perburuan, Raja Grafindo Persada, Jakarta: 1992. 